\title{
Hate Speech, Contentious Symbols and Politics of Memory: Survey Research on Croatian Citizens' Attitudes
}

\author{
NEBOJŠA BLANUŠA, ENES KULENOVIĆ \\ Faculty of Political Sciences, University of Zagreb
}

\begin{abstract}
Summary
The authors are presenting and interpreting the data on Croatian citizens' attitudes on regulating hate speech, contentious symbols and public commemoration. The data was collected in two nation-wide surveys conducted in 2016 and 2018. The data is analyzed within a normative framework of militant democracy versus anti-democratic tendencies. In the conclusion the authors, invoking the available data, advocate a minimal model of regulating public speech by focusing on public utterances of direct and symbolic hate speech.

Keywords: Hate Speech, Contentious Symbols, Free Speech, Extreme Speech
\end{abstract}

\section{Introduction}

This article deals with Croatian citizens' attitudes on banning hate speech, use of political symbols connected to totalitarian regimes and regulating collective memory through erecting public monuments and naming streets and town squares. Survey research on hate speech and contentious political symbols has been conducted in two waves on nationally representative samples ( $n=1000$ participants each), the first one in October 2016, and the second one in January 2018. All the questions asked in the first wave have been replicated and several new ones were added to improve the coverage of important issues, especially relating to the symbolic political speech and issues of public commemoration and politics of memory.

The first aim of the survey was to explore the Croatian citizens' attitudes towards legal ban of direct hate speech. The idea of hate speech, both as a theoretical and legal concept, is contentious. Political theorists, both supportive and dismissive of the usage of the concept of hate speech, point out that there is no consistent defi- 
nition of this concept (Malik, 2012; Heinze, 2016; Waldron, 2012). Legal scholars warn us that if we look comparatively at how different countries define and regulate hate speech in their legislation, we will find that there is "no universal standard for sanctioning hate speech" (Foxman and Wolf, 2013: 74; see also: Brown, 2015). However, difficulties relating to arriving at a comprehensive definition of hate speech should not blur the fact that some form of legislation designed to sanction hate speech is part of both international human rights standards developed after WWII (UDHR and ICCPR), the supranational level of the Council of Europe through rulings of the European Court of Human Rights (ECtHR) and the national legal framework of almost all constitutional democracies in the world today. ${ }^{1} \mathrm{Al}-$ though democratic countries approach the issue of hate speech in different ways, normatively speaking, variety in national legislation of different countries on hate speech can be seen as an advantage that allows international legal norms to be applied more meaningfully and consistently in a local context. ${ }^{2}$

As our survey covered the attitudes of Croatian citizens, our main reference point was the Croatian legal framework and Croatia's historical and political context in defining what should be put under the heading of hate speech and, more broadly, extreme political speech. Although there is no direct mentioning of hate speech in the Croatian Constitution and Criminal Code, both of these legal documents address the problem of public expressions of hate directed at members of specific groups. ${ }^{3}$ We have also taken into account the specific historical legacy of contentious political symbols and slogans connected to fascist Ustasha regime during WWII and Tito's communist dictatorship in the second part of the $20^{\text {th }}$ century.

Nevertheless, given the contentious aspect of the concept of hate speech, rather than using a comprehensive definition of hate speech in our survey, we have relied

${ }^{1}$ One exemption here is the USA whose $1^{\text {st }}$ Amendment of the Constitution forbids government to make any laws limiting free speech of its citizens. For a more detailed account of the relationship between the $1^{\text {st }}$ Amendment of the US Constitution and hate speech, see: Abrams, 2012; Strum, 1999; Walker, 1994.

2 This is an argument put forward by Bhikhu Parekh: "Every form of speech occurs within a particular historical and cultural context, and its content, import, insinuations, and moral and emotional significance are inseparable from, and can only be determined in the light of, that context" (Parekh, 2012: 41).

3 The Constitution proclaims in Article 39 that "any call for or incitement to war or use of violence, to national, racial or religious hatred, or any form of intolerance shall be prohibited and punishable by law". In the same vein, Article 325 of the Criminal Code bans "instigating violence or hatred directed against a group of persons or a member of such a group on account of their race, religion, national or ethnic origin, descent, colour, gender, sexual orientation, gender identity, disability or any other characteristics". 
on several key features to describe such speech. The first key feature is its public character, while its second core feature is that such speech - which can be verbal, written or expressed through symbols - has to target individual members of groups or groups as a whole based on their ascriptive characteristics such as race, gender, nationality, religion, ethnicity, sexual orientation, disability, etc. (see: Kulenović, 2016). To make questions as clear as possible we focused on the two most obvious and least controversial aspects of public hate speech: calls for violence and calls for discrimination against members of specific groups (leaving aside complex issues of what discrimination might actually entail or how to define specific groups whose members are victims of hate speech). Apart from public calls for violence or discrimination as forms of direct hate speech, we also addressed the question of symbolic hate speech, best represented in public display of Nazi signs and slogans. Such displays reveal support for ideology and political regime dedicated to discrimination, oppression, mass murder and even extermination of groups deemed by this ideology as inferior and parasitic. Therefore, although use of such symbols or slogans does not represent a direct form of hate speech, it can justifiably be understood as a form of symbolic hate speech.

Our survey went beyond what could be recognized as direct or symbolic hate speech and explored citizens' attitudes towards banning controversial political symbols, essentially symbols associated with fascism and communism. Public use of Nazi insignia or slogans can be perceived as both symbolic hate speech and a form of extreme speech through public declaration of sympathy and support for Nazi ideology and fascist regimes. ${ }^{4}$ Communist symbols and slogans usually do not fall under the heading of hate speech as they do not convey a message of racial or any other inferiority of the members of specific groups, but they can be interpreted as giving public support to anti-democratic and totalitarian political solutions. Hence, use of these symbols and slogans can be described as contentious and a form of extreme speech. The survey also covered signs and slogans used historically in Croatia during WWII by the Ustasha movement and regime and communist partisans and, later, Tito's regime. Furthermore, in the 2018 survey, we extended our research to cover questions of collective political memory by addressing the issue of removing the monuments and names of town squares and streets venerating persons or events from NDH (Independent State of Croatia) or NOB (People's Liberation Struggle) history.

The main research questions in this article are:

${ }^{4}$ Here we use 'fascist' as an umbrella term that covers far-right nationalistic movements and their ideology, including different historical regimes that embodied this ideology (such as Nazi Third Reich, Mussolini's fascist Italy or Croatian Ustasha). 
1. How prone are Croatian citizens to ban hate speech and extreme speech?

2. Are there some more general tendencies in their willingness to ban hate speech and extreme speech?

3. Can we discern which of these tendencies reflect a strong support for the idea of militant democracy (protection of democracy from ideas and movements that are deeply undemocratic), and which are an expression of antipluralist and anti-democratic attitude (to exclude one's ideological opponents from the public space)?

4. What are possible approaches to regulating hate speech and extreme speech and what are the advantages and disadvantages of each of these approaches?

The article is structured in such a way that each section tries to answer one of these research questions. In the first part we present the data collected by the survey and offer an initial interpretation of some of the results. In the second part we look at the possible reasons for the high level of support that Croatian citizens have for banning hate speech and extreme political speech. The third part introduces other variables - support for democratic values and institutions, anti-democratic and anti-pluralist attitudes, conspiratorial beliefs and family heritage - to further explain the high level of support for regulating hate speech and contentious symbols. In the concluding part we address the normative question of pros and cons of different models of regulating both direct and symbolic hate speech, extreme speech and collective memory through control of public space.

\section{Results}

To answer our first research question we asked our participants if several discriminatory activities and use of symbols of fascist and communist regimes should be legally sanctioned, as well as if street names and monuments which celebrate local traditions of those regimes should be removed from public spaces. In 2016 we posed five such questions, which are accompanied with six more in the 2018 survey. Results are shown in the next two figures (on pages 180 and 181).

First of all, around $80 \%$ of citizens would like to ban direct hate speech that expresses violence and discrimination of certain groups, as well as use of Nazi symbols. These tendencies show an increase from 2016 to $2018 .{ }^{5}$ On the other hand, there is a decrease in the percentage of those who would like to legally sanction communist symbols, such as the red star, from $61 \%$ in 2016 to $55 \%$ in 2018 , as well as an increase of proclivity to ban the local fascist slogan For the Home-

\footnotetext{
5 Performed Mann-Whitney $U$ tests for all three items with comparable data are statistically significant. $U_{1}=480523.500, p=0.002 ; U_{2}=470713.500, p=0.000 ; U_{3}=476522.500, p=0.001$.
} 
Figure 1. Tendency toward Legal Sanctions against Direct and Hate Speech and Contentious Symbols and Slogans (2016-2018)

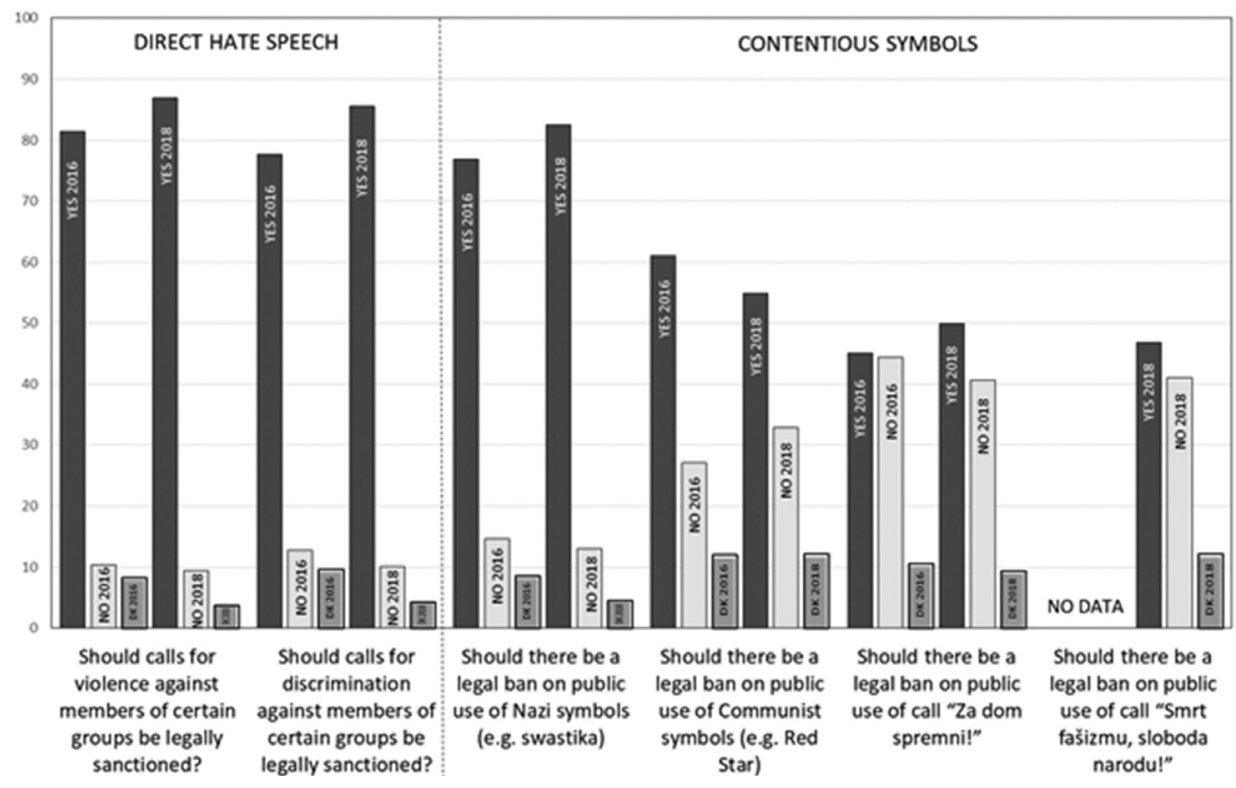

land Ready (Za dom spremni), from $45 \%$ to $50 \% .{ }^{6}$ Furthermore, in $2018,47 \%$ of Croatian citizens were prone to ban the local antifascist slogan Death to Fascism, Freedom to the People (Smrt fašizmu, sloboda narodu), opposed by $41 \%$ of their fellow citizens.

In our second survey in 2018, the proclivity to remove antifascist monuments and names of streets and squares was generally smaller than for monuments, streets and squares dedicated to the puppet fascist state of NDH. Unfortunately, this cannot be said for the Homeland War monuments that contain the slogan For the Homeland Ready. More than $47 \%$ of citizens oppose their removal. Those results are shown in the next figure.

The first issue we want to address is the high level of citizens' support for regulating public speech, the support that goes beyond what the current Croatian legal framework for sanctioning extreme speech requires. The majority of citizens in Croatia would support bans of hate speech, both in its direct and symbolic forms, in cases where such speech can be described as hate speech or voicing support for

${ }^{6} \mathrm{U}_{4}=466912.500, \mathrm{p}=0.000 ; \mathrm{U}_{5}=457656.500, \mathrm{p}=0.000$. 
Figure 2. Proclivity to Remove Monuments and Names of Streets and Squares Dedicated to NOB, NDH and the Homeland War

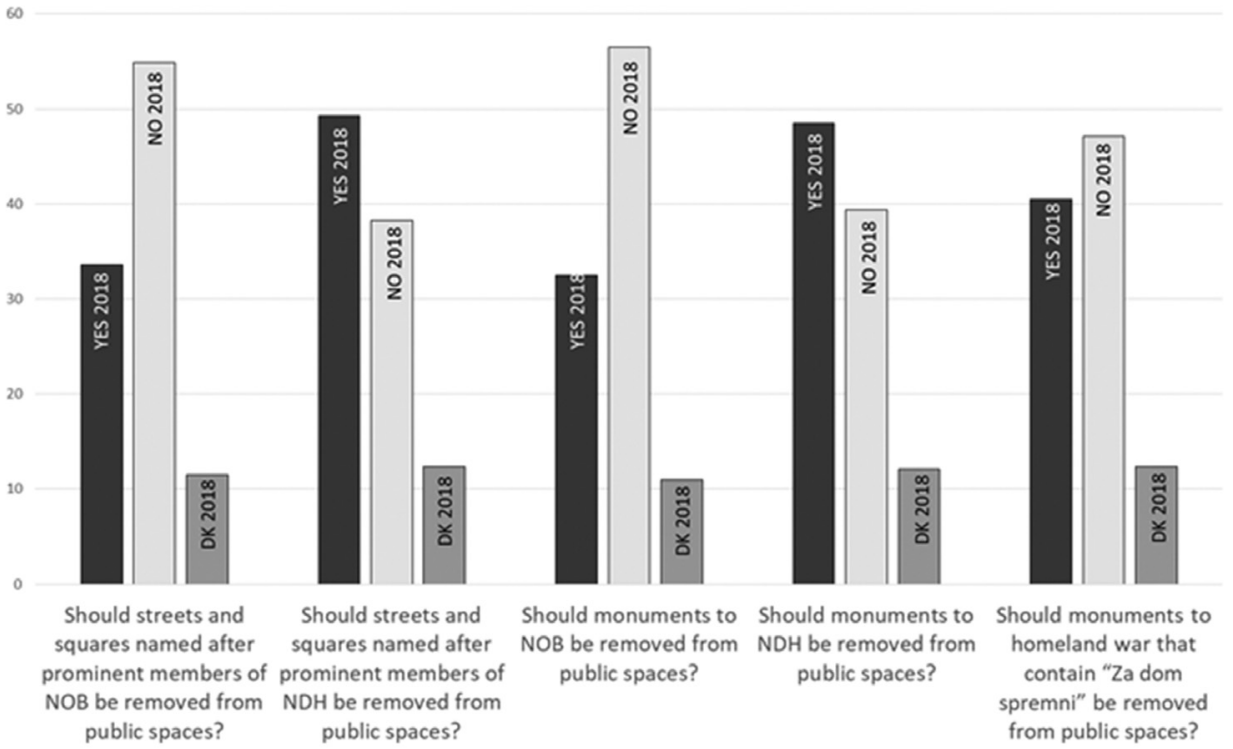

undemocratic regimes, institutions and values. The support for banning direct hate speech where such speech is advocating violence or discrimination against members of certain groups is at $81.4 \%$ in our 2016 survey and at $86.9 \%$ in the 2018 survey. This reflects the support for the existing legal framework on hate speech, as defined by Article 39 of the Constitution and by Article 325 of the Criminal Code. In the case of symbolic speech, there is a strong support for removing both Nazi and communist symbols from the public space. Legally sanctioning Nazi symbols, such as the swastika, can be interpreted in two ways: as a ban on symbolic hate speech directed at minority groups (first and foremost, Jewish and Roma people) ${ }^{7}$ and/or as a ban on voicing public support for totalitarian regimes and values of National Socialism. In 2016 and 2018 support for such a ban was at $76.9 \%$ and $82.5 \%$, respectively. Here again the values of the majority of Croatian citizens are reflected in an existing legal framework that sanctions the use of symbols of National Socialism in the public space.

${ }^{7}$ An essential part of the Nazi ideology is the racial theory by which Jewish and Roma people belong to parasitic races that should be eradicated. Hence, wearing a swastika is a symbolic equivalent of yelling "Kill all the Jews and Gypsies!" 
The percentage of Croatian citizens advocating legal ban on public display of communist symbols such as the red star or hammer and sickle is somewhat smaller, although it still involves the majority: $61 \%$ in 2016 and 54.9\% in 2018. As stated earlier, communist ideology does not contain advocacy of eradication of a whole people based on their racial or other ascriptive characteristics, therefore public use of such symbols should not be seen as a form of hate speech. However, using communist symbols, especially in the Croatian context, can be justifiably perceived as public promotion of undemocratic, authoritarian and even totalitarian regimes and ideology that has, historically, been invoked to justify grave violations of human rights. On the other hand, public use of communist symbols is much more ambiguous than use of Nazi symbols, as symbols such as red star can be interpreted in both negative (as an advocacy and an apology of undemocratic and authoritarian regimes) or positive way (as a support for labour movements, workers' rights or antifascist struggle). This was the argument invoked by ECHR in their 2008 ruling on Vajnai vs. Hungary. ${ }^{8}$ Attila Vajnai, vice-president of the Workers' Party was convicted by Hungarian courts for wearing a red star on his jacket during a demonstration as a violation of the law that forbids displaying totalitarian symbols in public. ECHR overruled that conviction as a violation of the freedom of expression, explaining that: "The Court is mindful of the fact that the well-known mass violations of human rights committed under communism discredited the symbolic value of the red star. However, in the Court's view, it cannot be understood as representing exclusively communist totalitarian rule, as the Government have implicitly conceded... It is clear that this star also still symbolizes the international workers' movement, struggling for a fairer society, as well as certain lawful political parties active in different member States". ${ }^{9}$ The existing Croatian legal framework follows the logic of ECHR's argument by allowing the use of communist symbols in the public sphere. The majority's opinion that such symbols should be legally banned is even more controversial if we take into account that the introductory part of the Croatian Constitution, in listing the historical foundations of Croatian statehood, refers to the Territorial Antifascist Council of the National Liberation of Croatia (1943), the Constitution of the People's Republic of Croatia (1947) and subsequent constitutions of the Socialist Republic of Croatia (1963-1990). Therefore, the communist symbols play an important part in the historical narrative of the continuity of Croatian statehood as presented in the Constitution.

This kind of ambiguity in public display of political symbols is reflected in the results for the two questions in our survey that refer to more local issues of banning the call For the Homeland Ready and the call Death to Fascism, Freedom to

${ }^{8}$ ECtHR, Vajnai vs. Hungary, Application no. 33629/06.

${ }^{9}$ Ibid., para 52. 
the People. The first one, For the Homeland Ready was used by members of the Ustasha movement during the WWII period in NDH, a quisling regime collaborating with Mussolini's fascists and the Third Reich. Not only did this regime commit grave human rights violations and crimes against humanity against members of the Serbian minority, it also passed racial laws and conducted genocidal policy against Croatia's Jewish and Roma population. For this reason, the public call of For the Homeland Ready represents both the use of symbolic hate speech and promotion of genocidal regime and genocidal policy. However, the support among Croatian citizens for banning For the Homeland Ready is much lower - at 45.1\% in 2016 and $49.9 \%$ in 2018 - than for banning public use of Nazi symbols. Possible reasons for this discrepancy could be explained by the fact that the call and insignia For the Homeland Ready was also used during the Homeland War in the 90s by certain voluntary army units. Hence, those Croatian citizens that would ban Nazi symbols, but would allow For the Homeland Ready probably ascribe more positive value of struggle for national independence and support for war veterans to the latter, ignoring the negative aspects of using this slogan in public. ${ }^{10}$

In our 2018 survey we extended the questionnaire to include the question should there be a legal ban on public use of the call Death to Fascism, Freedom to the People, the slogan that was used by communist partisans in WWII and later, in communist Yugoslavia, as a rallying cry for Tito's regime. The ambiguity arises because of the historical complexity where Death to Fascism, Freedom to the People can be interpreted as both an expression of affirmation of antifascism and/or as a validation of Tito's dictatorship. This ambiguity is echoed in the results of the survey where $46.8 \%$ of citizens would support the ban on public use of the slogan Death to Fascism, Freedom to the People, while $41.1 \%$ believe this slogan should not be banned. The current legal framework bans the use of For the Homeland Ready, but does not ban Death to Fascism, Freedom to the People. Again, the majority of citizens advocate a stronger ban on the use of contentious political symbols in the public space than is required by existing laws regulating public speech.

Our 2018 survey also included questions dealing with symbolic speech and collective memory by asking if streets and town squares named after prominent members of NDH and NOB should be renamed and if monuments to NDH or NOB should be removed from public spaces. In this case, the majority of citizens make a clear distinction between the historical legacy of NDH versus the historical legacy of

10 This reinterpretation of "Za dom spremni" disregards a deeply problematic point that those who were using that call in the Homeland War were themselves, consciously or less consciously, involved in revisionist justification of Ustasha regime as a genuine movement for Croatian independence and rationalization of the prosecution of the Serbian minority as a legitimate pursuit of Croatian national interests. 
NOB: $49.3 \%$ would not allow streets and town squares to be named after prominent members of NDH, while only $33.6 \%$ feel the same about historical figures connected to NOB. When it comes to public monuments the results are similar to the previous case, with $48.5 \%$ citizens not supporting monuments to $\mathrm{NDH}$ and $32.5 \%$ not supporting monuments to NOB. However, when we asked if the monuments to the Homeland War that contain For the Homeland Ready should be removed from public spaces, $40.5 \%$ of citizens believe that they should be removed, while $47.1 \%$ hold an opposite view. Once again, the results show that a certain percentage of citizens hold that For the Homeland Ready does not necessarily mean an expression of support for the ideas of National Socialism or support for NDH and its fascist and racist ideology, but in a certain context can be viewed in a positive light as a support for veterans of the Homeland War and struggle for Croatia's independence in the 1990s.

\section{Militant Democracy and/or Anti-democratic Tendencies}

How should we interpret the results from both 2016 and 2018 surveys that clearly show a higher level of support by Croatian citizens for banning forms of public speech than the current legal framework dealing with hate speech and other forms of extreme political speech requires? One possible approach is to look at this strong tendency to control and regulate extreme political speech in two possible ways: first, as a support for the ideal of militant democracy or, second, as evidence of anti-democratic and anti-pluralist sentiments. The former explanation would show a strong dedication to protecting democratic institutions and pluralist values of tolerance, inclusion and equal standing. The latter would suggest propensity for the anti-democratic solution of using the monopoly of the state to ban one's ideological opponents from entering and participating in the public sphere.

The concept of militant democracy (streitbare Demokratie) was introduced by German legal scholar Karl Loewenstein in two articles published in American Political Science Review in 1937 (Loewenstein, 1937a; 1937b). ${ }^{11}$ The core idea that Loewenstein presented is that democracies can and should protect themselves from the ideas and movements that are deeply undemocratic and whose goal is to use freedoms provided by democracies to destroy democracy itself. "Democracy and democratic tolerance", argued Loewenstein, "have been used for their own destruction" (Loewenstein, 1937a: 423). The scenario that Loewenstein had in mind was, of course, takeover of the German state by the Nazis and the destruction of the Weimar Republic. The protection of democratic institutions and values should manifest itself in two main areas. The first one is a legal ban of those political parties that refuse to accept basic democratic values of equal citizenship, fair political competition

${ }^{11}$ For a more detailed account of Loewenstein's work and the development of the concept of militant democracy itself, see: Cliteur and Rijpkema, 2012. 
through elections, rejection of violence as a political tactic and recognition of political and social rights of all citizens. The second one is a ban on certain forms of public speech and especially propaganda directed against citizens' ascriptive characteristics and group membership. When discussing how different European states have successfully applied instruments of militant democracy, Loewenstein advocates "forbidding incitement and agitation against and baiting of particular sections of the people because of their race, political attitude, or religious creed - in particular, because of their allegiance to the existing republican and democratic form of government" (Loewenstein, 1937b: 651). In short, he is talking about the ban on hate speech that was later extended, as the model of militant democracy developed, to sanctioning denial of genocide or crimes against humanity, as well as glorification of totalitarian regimes. ${ }^{12}$ The survival of the democratic order takes precedence over the right of free association and assembly, as well as right to free speech. In the aftermath of WWII, this idea was incorporated in the Constitution of Western Germany, but also in the Croatian Constitution that bans incitement to war and violence, calls for racial, religious or ethnic hate and intolerance (Article 39) and political parties that through their program or actions undermine or endanger the free democratic order (Article 6).

Strong support for banning direct hate speech, symbolic hate speech and types of extreme public speech that shows support for symbols of totalitarian regimes could be interpreted as a dedication to upholding the democratic order and its values though legal and institutional implementation of the idea of militant democracy. However, a more sinister interpretation of the willingness of Croatian citizens to regulate public speech in a more comprehensive way than the current legal framework allows, would be exactly the opposite of embracing the ideal of militant democracy. This interpretation would question citizens' dedication to democratic values and the democratic institutional order by suggesting that readiness to limit free speech derives from anti-pluralist tendency to silence one's political opponents, as well as those with whose ideology and worldview one disagrees. One obvious way to decide between the two options would be to look at the level of consistency when it comes to advocating legal regulation of free speech. So, for example, if one thinks a state should allow racist, homophobic or sexists public speech, but would ban the red star or Death to Fascism, Freedom to the People, this would clearly suggest anti-pluralist and anti-democratic tendencies. A more complex approach requires taking into account variables such as support for democratic values and institutions, anti-democratic and anti-pluralist attitudes, conspiratorial beliefs about democra-

12 This later extension echoes Loewenstein's warning that "it should be remembered that under the Weimar Republic, owing to the ill-advised yet inveterate attitude of the courts in interpreting the criminal code, Jews and Marxists as members of a group were left entirely without protection if they could not prove that the attack was directed personally against the complainant" (Loewenstein, 1937b: 651). 
tic institutions and other public agents, interpretations of WWII conflict in Croatia, and finally the family political heritage, in order to test the influence of local historical issues on Croatian citizens' attitudes about hate speech. Taking insights from Loewenstein's approach and his emphasis on "unchallengeable command", "high-pitched national enthusiasm", "the 'leadership' principle and abolition of liberal democracy and its institutions" and the political technique of "relentless selfadvertisement and propaganda" (Loewenstein, 1937a: 418, 421, 426) as clear signs of authoritarian leanings, we have looked at such variables as diffuse and more specific support for democracy, sense of endangered Nation, trust in political and social institutions, social distance towards ethnic minorities and need for a strong leader as general tendencies. Comparing these general tendencies to citizens' proclivity to ban hate speech and public use of contentious political symbols can help us understand if this proclivity is a reflection of support for militant democracy or/and an indication of anti-democratic and anti-pluralist predispositions.

\section{General Tendencies for Legal Sanctioning of Symbols of Totalitarian Regimes}

To discern if there are some more general tendencies in their willingness to ban different forms of hate speech as well as contentious symbols, we have conducted an exploratory Nonlinear Principal Component Analysis for categorical data (CATPCA) in SPSS 22. ${ }^{13}$ The best solution was the initial extraction that revealed three clearly interpretable components with eigen-values bigger than 1 . Items related to direct hate speech and legal ban on Nazi symbols were excluded due to their small variability and consequent disturbance of simple solution. ${ }^{14}$ The chosen solution is shown in the next table.

Our analysis revealed three latent dimensions (principal components), which together explain more than $85 \%$ of the variance. The first one is a general tendency toward legal sanctions against all symbols of totalitarian regimes. The other two are ideologically specific and selective proclivities. The second component is expressed as selective proclivity to ban only communist symbols, and the third one is the completely opposite tendency to ban only fascist symbols. Usually, it would be logical to expect a negative correlation between these two selective tendencies. Nevertheless, our results suggest a sort of compartmentalization and parallel modes of thinking in terms of what kind of contentious symbols to ban that can be differentially activated in exact cases, due to overdetermined meaning and various his-

${ }^{13}$ For the purpose of analysis we have recoded our data into ordinary scales where the answer $\mathrm{NO}=1, \mathrm{DK}=2, \mathrm{YES}=3$.

${ }^{14}$ As rotation options are not available within CATPCA in SPSS 22, the VARIMAX, PROMAX and DIRECT OBLIMIN rotations were then performed by saving the transformed variables and submitting them to a linear PCA with those rotations. Nevertheless, the initial extraction was the most interpretable solution and completely the same as the one obtained by CATPCA. 
Table 1. CATPCA Structure of Symbolic Hate Speech

\begin{tabular}{|c|c|c|c|}
\hline & $\begin{array}{c}\text { General } \\
\text { tendency to } \\
\text { ban symbols } \\
\text { of totalitarian } \\
\text { regimes }\end{array}$ & $\begin{array}{l}\text { Proclivity to } \\
\text { ban communist } \\
\text { symbols and to } \\
\text { preserve fascist } \\
\text { symbols }\end{array}$ & $\begin{array}{l}\text { Proclivity to ban } \\
\text { fascist symbols } \\
\text { and to preserve } \\
\text { communist } \\
\text { symbols }\end{array}$ \\
\hline $\begin{array}{l}\text { Streets and squares named after prominent } \\
\text { members of NOB }\end{array}$ & .796 & & -.422 \\
\hline $\begin{array}{l}\text { Streets and squares named after prominent } \\
\text { members of NDH }\end{array}$ & .827 & -.415 & \\
\hline Monuments dedicated to NOB & .795 & & -.438 \\
\hline Monuments dedicated to NDH & .820 & -.421 & \\
\hline $\begin{array}{l}\text { Monuments dedicated to the Homeland War } \\
\text { that contain "Za dom spremni" } \\
\text { (For the Homeland Ready) }\end{array}$ & .717 & -.475 & \\
\hline $\begin{array}{l}\text { Public use of Communist symbols } \\
\text { (e.g. the Red Star) }\end{array}$ & .432 & .758 & \\
\hline $\begin{array}{l}\text { Public use of call "Za dom spremni" } \\
\text { (For the Homeland Ready) }\end{array}$ & .577 & & .706 \\
\hline $\begin{array}{l}\text { Public use of call "Smrt fašizmu, } \\
\text { sloboda narodu" (Death to Fascism, } \\
\text { Freedom to the People) }\end{array}$ & .482 & .753 & \\
\hline Eigen-value & 3.888 & 1.882 & 1.077 \\
\hline$\%$ of the explained variance & 48.5 & 23.5 & 13.5 \\
\hline KMO & \multicolumn{3}{|c|}{0,729} \\
\hline $\begin{array}{l}\text { Bartlett's test of the significance } \\
\text { of the correlation matrix }\end{array}$ & \multicolumn{3}{|c|}{ Chi-square $=6250.814, \mathrm{df}=28, \mathrm{sig}=0.000$} \\
\hline
\end{tabular}

torical experiences with political and military agents who were acting under those ideological signs and slogans in different periods of the $20^{\text {th }}$ century. For example, someone can express a general tendency to prohibit all signs because of their antidemocratic character. The same person can also be prone to ban fascist symbols because his or her great-grandfather was a member of NOB movement, and simultaneously to be against communist symbols and prone to preserve monuments dedicated to the Homeland War that contain For the Homeland Ready because, for example, his or her relative was killed by the Yugoslav People's Army as a member of military units fighting under the slogan For the Homeland Ready. Different seemingly controversial cases of historical experiences are also possible. As it realistically reflects a variety of possible explanations, it seems reasonable to retain the chosen component structure. That leads us to the next research problem. 
To discern which of these aggregated tendencies reflect a strong support for the idea of militant democracy and which are an expression of anti-pluralist and anti-democratic attitude we obtained separate regression analyses for each of the components as criterion variables. ${ }^{15}$ For this purpose we used in our analysis several hypothetical predictors in the form of direct pro- and anti-democratic attitudes, then specific attitudes which are usually related to lower support for the democratic order, and finally several attitudes related to World War II and its ideological derivatives important for the development of discourse about NOB and NDH traditions. To be more precise, we have performed hierarchical regression analysis on each tendency to ban signs and slogans by using four groups of predictors. The first group included variables of direct democratic support, such as diffuse and specific support for democracy (Easton, 1975; 1976), general trust in political and social institutions, need for an inclusive government (in terms of normative opinion how often the government should include various political and social actors in their decision-making processes), general support for civil society, as well as several indicators of anti-democratic attitudes, such as authoritarianism, need for a strong leader, and populist attitudes (Castanho Silva et al., 2018). The second group of predictors included several indicators that can lead to the "suspension" of democratic values and pluralism, such as the sense of endangered national community, social distance toward ethnic and other minorities, and anti-immigration attitude. The third group of predictors focuses on the peculiar form of distrust expressed in different forms of beliefs in conspiracy theories. These conspiracy theories deal with assumed criminal and immoral activities of the whole range of political and economic agents, on local, state, international and global levels. This group included scales such as general conspiratorial mentality (Bruder et al., 2013), belief in global conspiracy theories, belief in local conspiracy theories related to internal and external politics in Croatia (Blanuša, 2011; 2013), as well as two newly developed scales to measure the support for non-transparent "shadow government" and belief in anti-elitist conspiracy theories. As the symbols of totalitarian regimes used in this study are related to World War II and the period of Yugoslavia, the last group of predictors expresses attitudes toward the role of fascist and antifascist legacy in Croatia, as well as opinions about prominent and controversial local political leaders from the $20^{\text {th }}$ century. As we observed in our previous research (Blanuša, 2013) that the political cleavage from World War II reproduces itself in actual left-right discourse and political positioning of Croatian citizens, the last predictor involved was the left-right self-perception. All groups of predictors are listed in the next table, together with hypotheses as to whether they contribute to the support of democracy (marked as "+") or to the

${ }^{15}$ We used this technique because of the generally explorative character of our study and the nonexistence of previous theoretical models that could be tested in certain conformational procedures. 
Table 2. Selected Predictors for Regression Analysis of Tendencies to Ban Symbolic Hate Speech

\begin{tabular}{|c|c|c|c|c|c|c|c|}
\hline \multicolumn{2}{|c|}{$\begin{array}{c}\text { Direct (anti)democratic } \\
\text { support }\end{array}$} & \multicolumn{2}{|c|}{$\begin{array}{l}\text { Anti-democratic and } \\
\text { anti-pluralist attitudes }\end{array}$} & \multicolumn{2}{|l|}{ Conspiratorial beliefs } & \multicolumn{2}{|l|}{ Political cleavages } \\
\hline $\begin{array}{l}\text { Diffuse support } \\
\text { for democracy }\end{array}$ & + & $\begin{array}{c}\text { Sense of endangered } \\
\text { Nation }\end{array}$ & - & $\begin{array}{l}\text { Conspiratorial } \\
\text { mentality }\end{array}$ & - & $\begin{array}{l}\text { Belief that Croats } \\
\text { were victims, not } \\
\text { villains in WWII }\end{array}$ & - \\
\hline $\begin{array}{l}\text { Specific support for } \\
\text { democracy }\end{array}$ & + & $\begin{array}{l}\text { Social distance } \\
\text { toward ethnic } \\
\text { minorities } \\
\text { and others }\end{array}$ & - & $\begin{array}{l}\text { Belief in global } \\
\text { CTs }\end{array}$ & - & $\begin{array}{l}\text { Belief that Croatian } \\
\text { antifascism (NOB) } \\
\text { was an authentic } \\
\text { movement vs. NDH }\end{array}$ & + \\
\hline $\begin{array}{l}\text { Trust in political and } \\
\text { social institutions }\end{array}$ & + & $\begin{array}{l}\text { Anti-immigration } \\
\text { attitude }\end{array}$ & - & $\begin{array}{c}\text { Belief in } \\
\text { conspiracies } \\
\text { of the Croatian } \\
\text { government from } \\
\text { the 1990s } \\
\text { and its enemies }\end{array}$ & + & $\begin{array}{l}\text { Opinion about } \\
\text { Ante Starčević }\end{array}$ & 0 \\
\hline $\begin{array}{l}\text { Need for an } \\
\text { inclusive } \\
\text { government }\end{array}$ & + & & & $\begin{array}{l}\text { Belief in } \\
\text { conspiracies of } \\
\text { global agents and } \\
\text { their local helpers } \\
\text { against Croatia }\end{array}$ & - & $\begin{array}{l}\text { Opinion about } \\
\text { Stjepan Radić }\end{array}$ & + \\
\hline $\begin{array}{l}\text { Support for civil } \\
\text { society }\end{array}$ & + & & & $\begin{array}{l}\text { Support for shadow } \\
\text { government }\end{array}$ & - & $\begin{array}{l}\text { Opinion about } \\
\text { Ante Pavelić } \\
\text { (NDH leader) }\end{array}$ & - \\
\hline Authoritarianism & - & & & Anti-elitist CTs & + & $\begin{array}{c}\text { Opinion about } \\
\text { Josip Broz Tito } \\
\text { (NOB leader) }\end{array}$ & - \\
\hline Populism & - & & & & & $\begin{array}{l}\text { Opinion about } \\
\text { Franjo Tuđman }\end{array}$ & 0 \\
\hline $\begin{array}{c}\text { Need for a strong } \\
\text { leader }\end{array}$ & - & & & & & $\begin{array}{c}\text { Left-right } \\
\text { self-identification }\end{array}$ & - \\
\hline
\end{tabular}

anti-democratic attitude (marked as "-"). The opinions that were unclear in terms of support or opposition to democracy or potentially controversial are marked with " 0 ".

As we are interested to get an insight into how much each of these groups of predictors separately contribute to the explanation of each tendency to ban contentious symbols, as well as their summative contribution, in the next table we shall present separate regressions for each of four groups of predictors and then the final hierarchical analysis. In all those analyses we used the stepwise method to determine significant predictors. Their predictive power is estimated through standardized $\beta$ coefficients. 


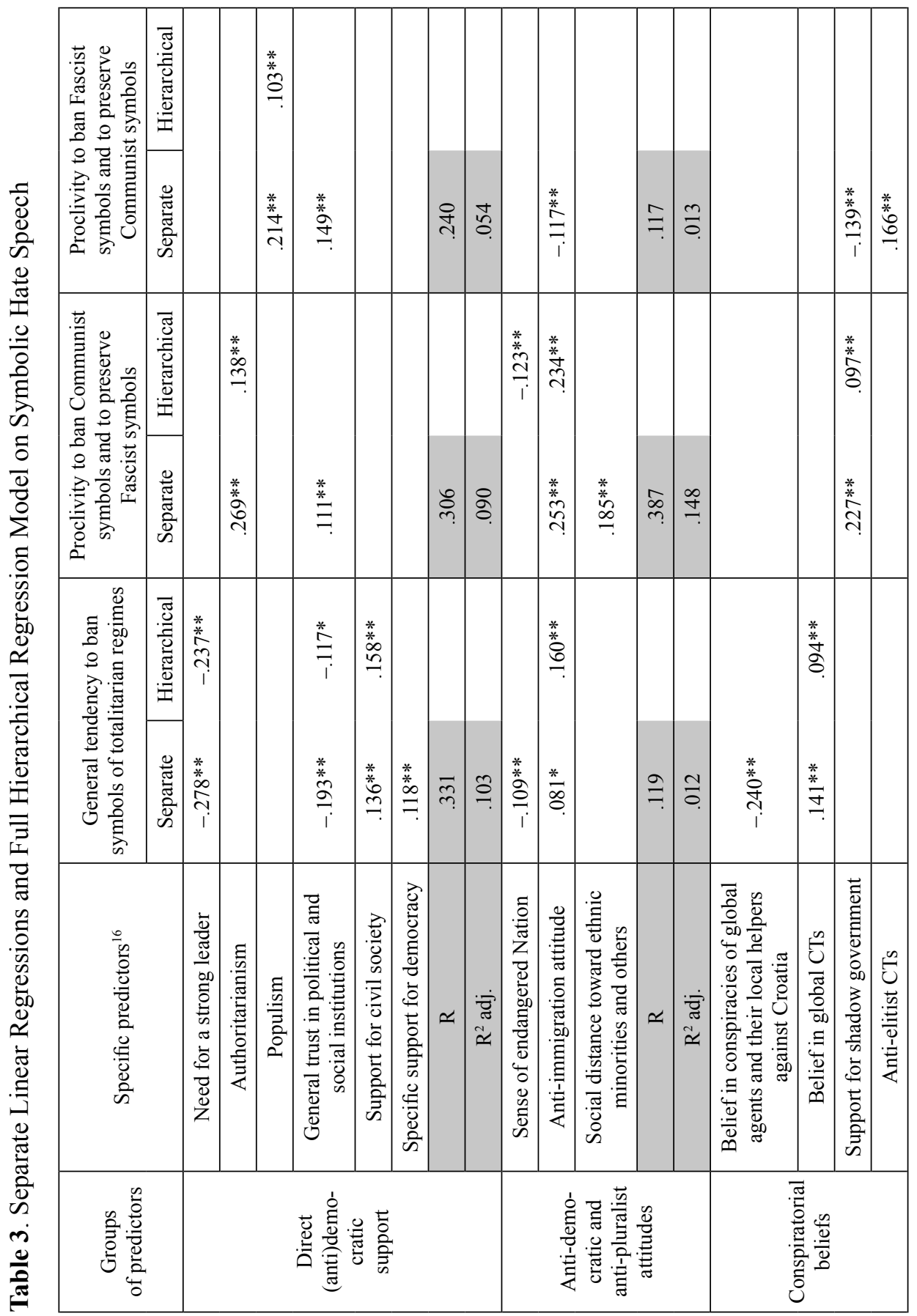




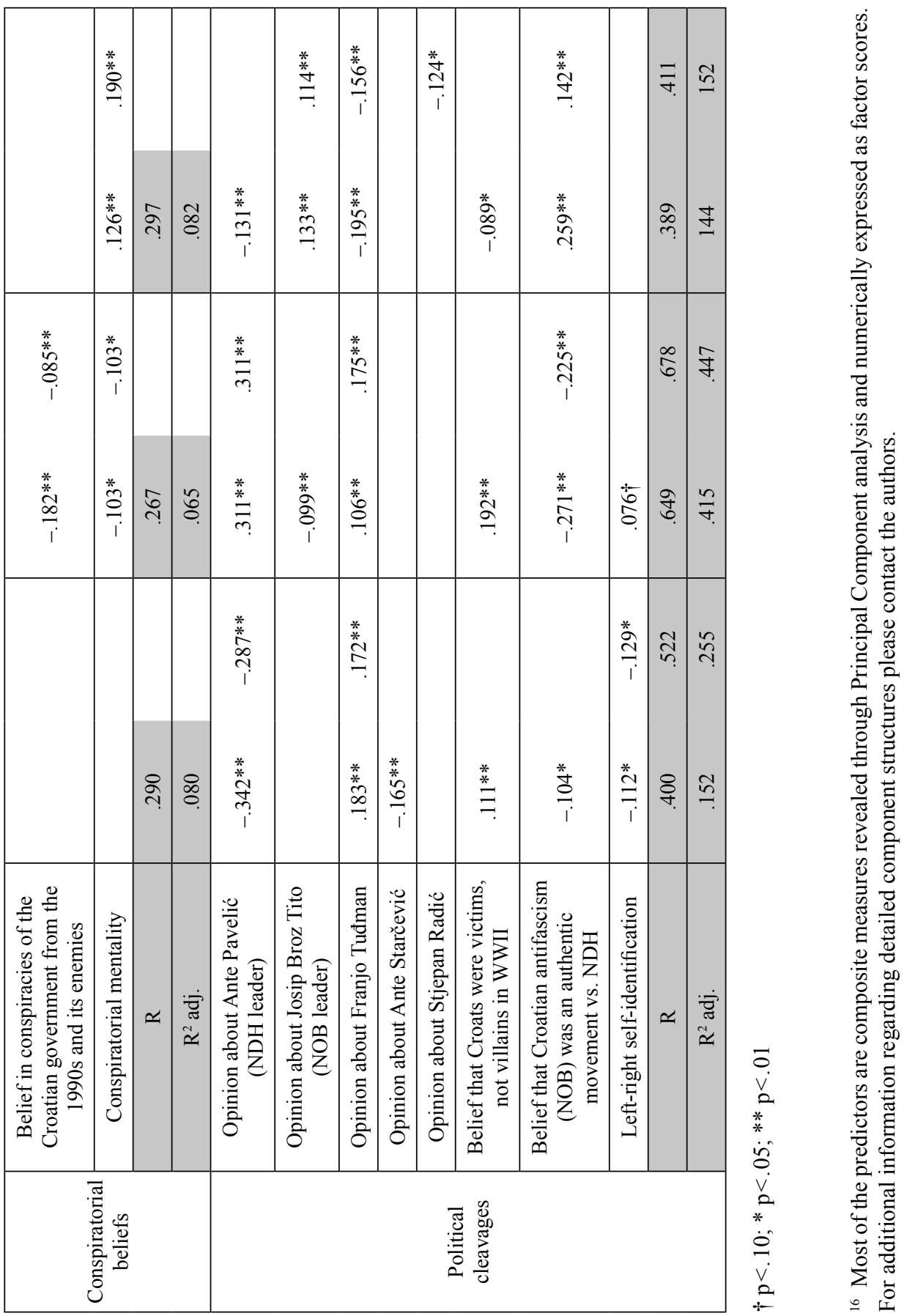


According to our results, the last group of predictors related to historical heritage - in the form of political cleavages between fascism and antifascism, including opinions about prominent and controversial political leaders - has the biggest predictive power for all criterion variables, especially for the proclivity to ban communist symbols and to preserve fascist symbols. Nevertheless, other groups of predictors also show their "influence" and explain a significant portion of the variance mostly in the line of our general hypotheses. In that sense, $10 \%$ of the variance of general tendency to ban symbols of totalitarian regimes can be explained by direct (anti)-democratic support. Particularly, skeptical citizens toward strong leaders, who criticize the functioning of political and social institutions, but simultaneously support democratic performance and civil society are more prone to express tendency to ban all symbols of totalitarian regimes. All this can be interpreted as a need for more effective institutional control of public use of contentious symbols. These results are in line with the hypothesis of militant democracy. They feel less that their nation is generally endangered, especially not by global agents and financial institutions, but simultaneously are slightly more prone to anti-immigrants attitude and belief in global conspiracy theories. The last two attitudes can be considered as an expression of need for more institutional control and protection by the state, especially due to recent immigration crisis, which was often interpreted through global conspiracy theories. But more security is often related to less democracy, especially in terms of human rights. Tendency to ban all totalitarian symbols is also strongly supported by negative opinion about NDH leader, Ante Pavelić, and another nationalist politician, Ante Starčević, which is consistent with an expression of slightly left-wing self-identification and consistent with the pro-democratic attitude. On the other hand, positive attitude toward the first Croatian president Franjo Tuđman also contributes slightly to the tendency toward legally sanctioning all the forms of hate speech and contentious symbols, but his rule was marked by serious threats to the democratic order. Furthermore, tendency to collective self-victimization is usually related to exclusivist national identity and anti-pluralist relationship to other groups. For all these reasons it seems that general tendency to ban all contentious symbols is only partially imbued with democratic inclinations. It is also significantly informed by the need for security and anti-pluralist attitudes. The same inclination, expressed in a smaller number of predictors, is also observed in our full hierarchical regression analysis shown in table 3 .

The most explained criterion variable in our hierarchical model is the proclivity to ban communist symbols and to preserve fascist symbols. Both separate and hierarchical analyses show that its best predictors are those related to political cleavages, but most of them are anti-democratically oriented. The citizens who show this proclivity have a positive attitude toward Ante Pavelić and Franjo Tuđman and 
Table 4. Proclivity to Ban Communist Symbols and to Preserve Fascist Symbols and Family Political Heritage

\begin{tabular}{|l|c|c|c|c|c|}
\hline \multirow{2}{*}{$\begin{array}{l}\text { How would you describe your family's dominant } \\
\text { position during World War II? }\end{array}$} & \multirow{2}{*}{$\mathrm{N}$} & \multicolumn{4}{|c|}{ Subset for alpha=0.10 } \\
\cline { 5 - 6 } & & 1 & 2 & 3 & 4 \\
\hline Partizan movement (NOB) - antifascists & 126 & -.7632 & & & \\
\hline On several military-political sides in the conflict & 92 & & -0.2030 & & \\
\hline Don't know & 157 & & 0.0463 & 0.0463 & \\
\hline Out of conflict & 456 & & 0.0810 & 0.0810 & \\
\hline Home Guards (NDH) - regular army units & 104 & & & & 0.2944 \\
\hline Ustasha (NDH) - fascists & 61 & & & & 0.6595 \\
\hline Sig. & & 1 & .399 & .560 & .132 \\
\hline F= 26.345, df $=\mathbf{5 . 9 9 3 , ~ s i g . = . 0 0 0}$ & & & & & \\
\hline
\end{tabular}

Means for groups in homogeneous subsets are displayed.

support NDH as an authentic movement. They are prone to authoritarianism, antiimmigration attitude, conspiratorial mentality, and tend to support "shadow government", and simultaneously oppose the idea that the Croatian government was involved in various conspiracies during the 1990s. According to these results, they are probably supporters of the right-wing historical revisionism. Besides, they strongly support the work of ultra-conservative pressure groups such as "U ime obitelji" (In the name offamily) and "Vigilare". ${ }^{17}$ As a result of One-Way ANOVA, the next table also shows that proclivity to ban communist symbols and to preserve fascist symbols is logically distributed according to the family political heritage from World War II. The heirs of the NDH tradition strongly support this proclivity, while the heirs of the NOB tradition strongly oppose it.

The least explained criterion variable in our models is the proclivity to ban fascist symbols and to preserve communist symbols. Although the strength of predictors is rather small, their political profile is relatively clear. Those citizens show tendency toward populist attitudes, together with similar inclinations, such as belief in anti-elitist conspiracy theories. They are also opposed to non-transparent shadow government, express general conspiratorial mentality, and take the side of antifascism in the political cleavage from World War II, by having a positive attitude toward Josip Broz Tito and a negative attitude toward Ante Pavelić, along with nega-

17 Proclivity to ban communist symbols and to preserve fascist symbols highly correlates with the support of these two groups $\left(\mathrm{r}_{1}=.504^{* *}, \mathrm{r}_{2}=.525^{* *}\right)$. 
Table 5. Proclivity to Ban Fascist Symbols and to Preserve Communist Symbols and Family Political Heritage

\begin{tabular}{|l|c|c|c|}
\hline \multirow{2}{*}{$\begin{array}{l}\text { How would you describe your family's dominant } \\
\text { position during World War II? }\end{array}$} & \multirow{N}{*}{$\mathrm{N}$} & \multicolumn{2}{|c|}{ Subset for alpha $=0.10$} \\
\cline { 3 - 4 } & & & \\
\hline Ustasha (NDH) - fascists & 61 & -.3137 & \\
\hline On several military-political sides in the conflict & 92 & -.2241 & \\
\hline Home Guards (NDH) - regular army units & 104 & -.1595 & \\
\hline Don't know & 157 & -.0330 & -.0330 \\
\hline Out of conflict & 456 & .0467 & .0467 \\
\hline Partizan movement (NOB) - antifascists & 126 & & .3207 \\
\hline Sig. & & .185 & .204 \\
\hline F=5.649, df=5.993, sig. $=\mathbf{. 0 0 0}$ & & \\
\hline
\end{tabular}

Means for groups in homogeneous subsets are displayed.

tive attitudes toward Franjo Tuđman and, somewhat surprisingly, Stjepan Radić. In line with the general argument, they believe that Croatian antifascism (NOB) was an authentic movement unlike the puppet fascist state of NDH. What they are trying to preserve is the positive legacy of the Croatian antifascist movement that was severely demonized in the last few decades in Croatia, which can explain their excessive mistrust revealed in conspiratorial thinking and populist attitudes. As a result of One-Way ANOVA, the next table also shows that the proclivity to ban fascist symbols and to preserve communist symbols is logically distributed according to the family political heritage from World War II. The heirs of the NOB tradition support this proclivity, while the heirs of the NDH tradition oppose it.

\section{Normative Models of Regulating Hate Speech and Extreme Speech}

In the concluding part we want to address the question of normative possibilities relating to legal regulation of hate speech using insights from the available data and our previous analysis. We will present four such possibilities and discuss the advantages and disadvantages of each of them in turn. The first option would be an existing legal framework that bans direct hate speech and public display of symbols and slogans associated with Nazism or the Ustasha regime, but puts no legal restrictions on public use of communist symbols or slogans. The ban on direct hate speech affirms the state's commitment to protect members of different groups, especially minority groups, from having their standing as equal citizens - by invoking violence or discrimination - put into question. As one of the core values of constitutional de- 
mocracy is the idea of equal citizenship, sanctioning direct hate speech serves two aims: first, to affirm equal standing of all citizens independently of race, ethnicity, gender, religion, sexual orientation or other ascriptive characteristics; second, to acknowledge the state's commitment to democratic values of inclusiveness, toleration and equality. ${ }^{18}$

When it comes to symbolic hate speech, the normative logic behind making a distinction between fascist vs. communist symbols rests on the perception of historical legacies and dangers that such legacies can have for maintaining basic democratic values and institutions. Both the fascist and communist political regimes have committed grave human rights violations such as war crimes, crimes against humanity and, in the case of the Third Reich and its collaborator NDH, genocide. There is, however, a clear difference in fascist and communist ideologies and the values that these ideological frameworks invoke. The anti-humanism, call for unquestioning loyalty to strong leaders, necessity of violence and theories of racial superiority that form an integral part of fascist ideology are anathema to any democratic order in such a way that core communist values of equality, fair distribution and putting an end to economic exploitation are not. Totalitarian order and massive human rights abuses are a betrayal of the communist ideal, but a realization of the fascist ideal. As public display of symbols can be seen as giving support to a certain political order or a certain set of values, there is no ambiguity in public use of fascist symbols and slogans, in the way there is when it comes to communist symbols. Additionally, use of fascist symbols always conveys a message of willingness to overthrow an existing democratic order, which is not necessarily the case with the use of communist symbols. ECHR followed the line of these two arguments in the aforementioned Vajnai vs. Hungary case, when it maintained that public use of communist symbols does not necessarily represent the support for totalitarian regimes nor willingness to endanger democratic order through violent means, as it can also be interpreted as a dedication to workers' rights and social equality and justice.

The advantage of this first approach to regulate extreme political speech in the public space is that it corresponds to the legal tradition of dealing with hate speech endorsed by most of the EU members, as well as ECHR. Also, in the Croatian context, banning fascist symbols while allowing communist symbols corresponds to the way the two opposing ideologies are presented in the Croatian Constitution where the legacy of NOB is endorsed as a part of the historical narrative of Croatian

${ }^{18}$ Legal philosopher Jeremy Waldron talks about harm in hate speech that manifests itself in two ways. First, hate speech is an affront to the political standing of equal citizenship of an individual. Second, hate speech is an attack on the basic values and institutions of constitutional democracy. In his words: "hate speech is both a calculated affront to the dignity of vulnerable members of society and a calculated assault on the public good of inclusiveness" (Waldron, 2012: 5-6). 
statehood, while the legacy of NDH is rejected. The disadvantage of this approach lies in the fact that citizens might feel that this normative distinction between political regimes and ideology is mere theoretical nitpicking and somewhat arbitrary and inconsistent legal regulation of the symbols of only the far-right, but not the far-left ideology and the political order.

This brings us to the second approach which argues for a ban on not only direct hate speech and fascist symbols, but also a ban on communist symbols. This would be an approach supported by, as our data shows, the majority of Croatian citizens. Here communism and fascism, by focusing less on the ideology and more on the $20^{\text {th }}$-century historical record of communist and fascist states, are perceived as two extreme poles of anti-democratic, anti-pluralist and totalitarian politics. Ban of symbols associated with these extreme political options would help exclude from public space those committed to abolishing constitutional democracy, but also reject both the fascist and the communist historical legacy that plagued Croatia. In this approach special emphasis is given to crimes and human rights violations committed under the banner of fascism and communism. The benefit of this approach is that it is committed to banning hate speech in all its forms, but also banning acts of public support for any anti-democratic regime or political solution. By taking a historical record of atrocities committed by both communist and fascist regimes in the $20^{\text {th }}$ century, it consistently rejects both options as deeply undemocratic. The problem with this approach is that it fails to recognize a more ambiguous character of communist symbols that does not exist when it comes to fascist symbols, as values and ideals of communism do not imply rejection of a fair and democratic society in such a way that those of fascism inevitably do. This is the main reason why communist symbols are not legally banned in European countries, even in the countries that were under the rule of communist dictatorship for almost half a century.

The third option would be a kind of combination between the first and the second approach, but less restricted in its application by taking into account the local context in which certain symbols are used. This was the option that the Council for Dealing with the Consequences of the Rule of Undemocratic Regimes, a government-established body of academics and scholars, opted for in their 2018 report. ${ }^{19}$ The advantage of this approach is in giving a local context much more weight than the two previous approaches by acknowledging that symbols used in public space can convey multiple messages and, given a specific context, can acquire altered meaning in different situations. For example, waiving a red star flag and shouting Death to Fascism, Freedom to the People during commemoration of the Bleiburg victims is a clear provocation designed to justify extrajudicial killings committed

19 See: Dokument dijaloga: temeljna polazišta i preporuke o posebnom normativnom uređenju simbola, znakovlja i drugih obilježja totalitarnih režima i pokreta, 2018. 
by communist partisans in the wake of WWII. However, the same flag and the same slogan used in a different context - at a rally for workers' rights or an antifascist demonstration - can have a more positive message. However, this approach can also be perceived as relying too much on political compromise and sacrificing certain normative standards for political expediency. When the report was published, it was criticized both by conservative and more liberal pundits and intellectuals. The former thought that the report, treating the use of communist symbols more favorably than the fascist ones, failed to equate two totalitarianisms sufficiently. The latter argued that allowing the use of For the Homeland Ready in certain contexts would give legitimacy to far-right fascist symbols, legitimacy they do not deserve to have in a democratic society, pandering to revisionist history of vindicating NDH as a failed but justifiable political project.

The final approach would entail embracing the "American model" on hate speech and the use of symbols of totalitarian regimes in public places. ${ }^{20}$ Basically, the state should allow any public utterance, verbal, written or symbolic, no matter how extreme it might seem, as long as it does not involve a direct physical threat to a member or members of certain groups. The normative logic this approach relies on is that of content neutrality where the state should refrain from regulating free speech unless it can be proven that such speech will directly lead to criminal acts. Hence, there would be no legal restriction on the use of either communist or fascist symbols, while hate speech would be banned only in those instances where such speech leads to direct harm and immediate danger to individuals. The advantage of this approach, as most proponents of the "American model" of free speech regulation argue, is that it diminishes the chances of the abuse of state power through hate speech and extreme speech legislation (see: Post, 2012; Heinze, 2016). More importantly, this approach clearly acknowledges the importance of the right to free speech, even when this right is used for publicly conveying hateful messages, for the ideal of democratic legitimacy. As prominent legal scholar Ronald Dworkin argued, the democratic state loses its legitimacy when it imposes laws on its citizens and demands that those laws are respected, if it has previously excluded a certain number of citizens from openly deliberating on the validity of those laws by curtailing their right to free speech (Dworkin, 1996; 2009). However, a possible advantage of the European over the American model of regulating free speech is that it looks at hate speech as an attempt to exclude certain (usually minority) groups from the political community, an exclusion that can be more detrimental to democracy than the type of exclusion Dworkin talks about. Additionally, the ban on the use of contentious symbols voicing support for totalitarian political projects, especially in

${ }^{20}$ For most recent vocal advocate of applying the American approach to all democratic societies, see: Heinze, 2016. For applying this model in Croatia, see: Cvijanović, 2016. 
cases such as Nazi insignia that also represent symbolic hate speech, confirms the state's commitment to protection of human rights and the democratic ideal of inclusion itself by the removal of anti-democratic and deeply intolerant rhetoric from the public space. The historical paradigm for the European model is the experience of racist propaganda used by Nazis during the Weimar Republic and the Third Reich that fed the politics of genocide, crimes against humanity and the rise of totalitarian order (Holmes, 2012).

\section{Conclusion}

Our survey research dealt with citizens' tendency to legally sanction hate speech, as well as contentious symbols associated with fascism and communism, including those historically linked to Ustasha or communist movements and regimes. It has generally shown that more than $80 \%$ would ban direct hate speech that expresses violence and discrimination of certain groups, as well as use of Nazi symbols. These tendencies even increased from 2016 to 2018. Tendency to ban extreme speech reflected through contentious symbols and slogans is significantly lower and varies from $47 \%$ for the local antifascist slogan Death to Fascism, Freedom to the People to 55\% for the red star in 2018. Furthermore, from 2016 to 2018 the proclivity to ban the local fascist slogan For the Homeland Ready significantly increased to $50 \%$, as a sign of growing criticism and aversion. Similar results are obtained for local streets names and monuments dedicated to fascist puppet state of NDH, while the majority of citizens would not ban antifascist street names and monuments. Nevertheless, when we move to recent violent history, relative majority of $47 \%$ of citizens advocates preservation of the Homeland War monuments that contain the fascist slogan For the Homeland Ready. Such tendency to use different, multilayered and sometimes inconsistent historico-political criteria is also expressed in the general structure of aggregated tendencies. Chosen predictors show that support of militant democracy can only be applied to the "general tendency" to ban symbols of both totalitarian regimes. Moreover, this tendency is best predicted by the political cleavage from WWII between fascists and antifascists. In that sense, those who negatively value the leader of NDH, Ante Pavelić, positively value the first president of the Republic of Croatia, Franjo Tuđman and have more left-wing inclination are more strongly opposed to all anti-democratic insignia. This group of "political cleavage" predictors has the highest "influence" on the other two proclivities to ban communist and fascist symbols, street names and monuments, although in opposite directions. Both of these specific proclivities are in accordance with the family political heritage of those Croatians who support or oppose them. Another easily discernable insight from our results is the ideological compactness of those who would like to ban communist symbols and pre- 
serve fascist symbols, street names, and monuments. They show very problematic authoritarian, anti-democratic and anti-pluralist attitudes.

Given the results of the two surveys and our analysis, we can try and answer the question what would be the best model of regulating hate speech and extreme speech in Croatia. Should the Croatian legal framework regulating this issue be extended to be more in line with the attitudes of the majority? Is there a need to go beyond regulating direct and symbolic hate speech and extend the ban to cover public display of contentious symbols of both fascism and communism? Our position is that the existing model of regulating different forms of extreme speech is suitable for Croatia. The state should ban direct and symbolic hate speech, but refrain from prohibiting use of all politically contentious symbols, i.e. communist symbols and slogans. Some basic elements of militant democracy - banning anti-democratic political parties from entering democratic politics and sanctioning hateful public utterances - already exist in the Constitution and the Criminal Code. This allows for legal sanctioning of the use of direct and symbolic hate speech. As the right to freedom of speech is one of the core values of constitutional democratic order, this right should be curtailed only when there are overwhelming reasons to do so. It is far from clear that there are such reasons when it comes to banning all contentious symbols.

The level of restrictions imposed onto public space that militant democracy requires should reflect the level of real danger that the democratic order is facing at a given time. Although there is a rise in support for far-right movements, populist rhetoric and exclusionary politics in Europe today (and Croatia is no exception here), the threat to democracy is not as dramatic as it was in late 1930s when Loewenstein was advocating militant democracy and comprehensive legal solutions against fascist and authoritarian movements and regimes. Even in countries such as Poland and Hungary where there is an open endorsement of anti-pluralist and authoritarian policies by their governments, there is hardly a level of paramilitary violence, anti-Semitic propaganda and rejection of democratic values and institutions that marked the period of European politics Loewenstein is describing in his two essays. The same is true of Croatia. The core premise of militant democracy is to legally defend democratic institutions from their takeover by extreme antidemocratic organizations by curtailing the rights of assembly, association and free speech. In Croatia, far-right movements and political parties invoking authoritarian solutions are on the fringes of politics, hence there is no real danger for the democratic order from the extreme right or the extreme left which is practically nonexistent. It is not very convincing to assume that the majority of Croatian citizens would ban both fascist and communist symbols because of their fear of the real possibility of reemergence of fascist or communist dictatorship. As our analysis shows, a better explanation is that citizens' advocacy for banning these contentious sym- 
bols is rooted in the rejection of negative historical legacy and already determined trans-generational trauma (Blanuša, 2015) associated with these symbols. However, as pointed earlier by referencing the ruling of ECHR, communist symbols are too ambiguous to be read exclusively as voicing a support for totalitarian regimes. Does the same argument apply to fascist symbols? The answer is no for two reasons. First, such symbols are not ambiguous in any way as they are always an expression of ideas and values that are anathema to democratic order. Second, more importantly, such symbols promote an exclusionary ideology that denies equal standing to members of minority groups based on their ascriptive traits. This is true even of For the Homeland Ready: when this slogan is used as a part of commemoration of the soldiers who fought in the Homeland War, it is impossible to separate the positive value of patriotic struggle for Croatia's independence from revisionist acceptance of the legacy of fascist NDH and the prosecution of the Serbian minority as a legitimate political goal. Croatia is not facing a real threat of an overthrow of the democratic government by extreme right or extreme left organizations, but we are witnessing a rise in exclusionary political rhetoric, both on fringes and in mainstream politics, especially against the minorities. This is good reason for supporting a ban on both direct and symbolic hate speech, as well as advocating for a more consistent application of laws regulating such speech.

\section{REFERENCES}

Abrams, Floyd. 2012. On American Hate Speech Law, in: Herz, M. and Molnar, P. (eds.): The Content and Context of Hate Speech. Cambridge University Press. Cambridge: 116-126.

Blanuša, Nebojša. 2011. Teorije zavjera i hrvatska politička zbilja 1980 - 2007. Plejada. Zagreb.

Blanuša, Nebojša. 2013. Internal Memory Divided: Conspiratorial Thinking, Ideological and Historical Cleavages in Croatia; Lessons for Europe. European Quarterly of Political Attitudes and Mentalities, (2) 4: 16-33.

Blanuša, Nebojša. 2015. II svjetski rat kao transgeneracijska trauma: sablasti prošlosti među mladima u Hrvatskoj, in: Ilišin, V. (ed.): Demokratski potencijali mladih u Hrvatskoj. IDIZ i Centar za demokraciju i pravo Miko Tripalo. Zagreb: 125-144.

Brown, Alex. 2015. Hate Speech Law: A Philosophical Examination. Routledge. Abingdon.

Bruder, Martin et al. 2013. Measuring Individual Differences in Generic Beliefs in Conspiracy Theories across Cultures: Conspiracy Mentality Questionnaire. Frontiers in Psychology, (4) 225: 1-15. 
Castanho Silva, B., Andreadis, I., Anduiza, E., Blanuša, N., Morlet Corti, Y., Delfino, G., Rico, G., Ruth-Lovell, S. P., Spruyt, B., Steenbergen, M., Littvay, L. 2018. Public opinion surveys: A new scale, in: Hawkins, Kirk A. et al. (eds.): The Ideational Approach to Populism. Routledge. London.

Cliteur, Paul and Rijpkema, Bastiaan. 2012. The Foundations of Militant Democracy, in: Ellian, A. and Molier, G. (eds.): The State of Exception and Militant Democracy in a Time of Terror. Republic of Letters. Dordrecht: 227-272.

Cvijanović, Hrvoje. 2016. Govor kao verbalni i simbolički prostor slobode i političkog: američki poučak i govor mržnje u EU i Hrvatskoj, in: Kulenović, E. (ed.): Govor mržnje u Hrvatskoj. Političke analize. Zagreb.

Dokument dijaloga: temeljna polazišta i preporuke o posebnom normativnom uređenju simbola, znakovlja i drugih obilježja totalitarnih režima i pokreta, 2018.

Dworkin, Ronald. 1996. Freedom's Law. Oxford University Press. Oxford.

Dworkin, Ronald. 2009. Foreword, in: Hare, I. and Weinstein, J. (eds.): Extreme Speech and Democracy. Oxford University Press. Oxford: v-ix.

Easton, David. 1975. A reassessment of the concept of political support. British Journal of Political Science, (5) 4: 435-457.

Easton, David. 1976. Theoretical approaches to political support. Canadian Journal of Political Science, (9) 3: 431-448.

Foxman, Abraham and Wolf, Christopher. 2013. Viral Hate. Palgrave Macmillan. New York.

Heinze, Eric. 2016. Hate Speech and Democratic Citizenship. Oxford University Press. Oxford.

Holmes, Stephen. 2012. Waldron, Machiavelli, and Hate Speech, in: Herz, M. and Molnar, P. (eds.): The Content and Context of Hate Speech. Cambridge University Press. Cambridge: 345-351.

Kulenović, Enes. 2016. Sloboda govora i govor mržnje, in: Kulenović, E. (ed.): Govor mržnje u Hrvatskoj. Političke analize. Zagreb.

Loewenstein, Karl. 1937a. Militant Democracy and Fundamental Rights I. The American Political Science Review, (31) 3: 417-432.

Loewenstein, Karl. 1937b. Militant Democracy and Fundamental Rights II. The American Political Science Review, (31) 4: 638-658.

Malik, Kenan. 2012. Interview with Kenan Malik, in: Herz, M. and Molnar, P. (eds.): The Content and Context of Hate Speech. Cambridge University Press. Cambridge: 81-91.

Parekh, Bhikhu. 2012. Is There a Case for Banning Hate Speech?, in: Herz, M. and Molnar, P. (eds.): The Content and Context of Hate Speech. Cambridge University Press. Cambridge: 37-56. 
Post, Robert. 2012. Interview with Robert Post, in: Herz, M. and Molnar, P. (eds.): The Content and Context of Hate Speech. Cambridge University Press. Cambridge: 1136.

Strum, Philipa. 1999. When the Nazis Came to Skokie. University Press of Kansas. Lawrence.

Waldron, Jeremy. 2012. The Harm in Hate Speech. Harvard University Press. Boston.

Walker, Samuel. 1994. Hate Speech: The History of an American Controversy. University of Nebraska Press. Lincoln.

Mailing Addresses:

Nebojša Blanuša, Faculty of Political Sciences, University of Zagreb, Lepušićeva 6, 10000, Zagreb, Croatia. E-mail: nebojsa.blanusa@fpzg.hr

Enes Kulenović, Faculty of Political Sciences, University of Zagreb, Lepušićeva 6, 10000, Zagreb, Croatia.E-mail: ekulenovic@fpzg.hr 